\title{
Biomass production from fermented starch wastewater in photo-bioreactor with internal overflow recirculation
}

Pradthana Prachanurak, Chart Chiemchaisri*, Wilai Chiemchaisri, Kazuo Yamamoto

Department of Environmental Engineering, Faculty of Engineering, Kasetsart University, Bangkok, Thailand

50 Ngam Wong Wan Road, Chatuchak, Bangkok 10900, Thailand

* Corresponding author: Chart Chiemchaisri, Email: fengccc@ku.ac.th Tel (Fax) +6625790730 


\begin{abstract}
A photo-bioreactor with internal overflow recirculation was applied to treat real fermented starch wastewater and convert it to photosynthetic biomass for further utilization. The photo-bioreactor was operated at a hydraulic retention time of 10 days by circulating mixed liquor through overflow pipes and penetrating light through infrared transmitting filter. During the operation of 154 days, the average BOD and COD removals were $95 \%$ and $88 \%$, respectively. Majority of photosynthetic bacteria was found attached on pipes as biofilm contributed to $82 \%$ of total biomass production. Photosynthetic biomass yield was $0.51 \mathrm{~g}$ dried solid/g BOD removed and crude protein content of $0.58 \mathrm{~g} / \mathrm{g}$ dried solid. Rhodopseudomonas palustris was found in the photosynthetic system as the predominant bacterial group by denaturing gradient gel electrophoretic analysis (DGGE) and 16S rDNA sequencing method.
\end{abstract}

Keywords: overflow recirculation; photo-bioreactor; fermented starch wastewater; purple non-sulfur bacteria; Rhodopseudomonas palustris. 


\section{Introduction}

Anoxygenic phototrophic bacteria, especially purple non-sulfur bacteria (PNSB) are widely distributed in nature, such as, soil, water and wastewater (Okubo et al., 2006). They can grow both under light in anaerobic or micro-aerobic condition as photo-autotrophs and photoheterotrophs. They also can grow anaerobically in the dark using fermentation and aerobically in darkness using respiration (Kaewsuk et al., 2010). The application of PNSB has been used to treat various types of wastewater because of organic carbon can be directly converted to hydrogen gas (Liao et al., 2010) or biomass as single cell proteins, which are byproduct of the process. PNSB biomass is rich in proteins and vitamins, which is useful for fish feeding (Honda et al., 2006; Chiemchaisri et al., 2007). In the previous studies, it was found that some factors can be promoted for PNSB cultivation, such as, controlling the ORP below $-200 \mathrm{mV}$ for micro-aerobic or anaerobic condition under light radiation to keep PNSB (Kaewsuk et al., 2010), installing an infrared transmitting filter to allow only infrared waveband passing through for PNSB growth under anaerobic condition and control microalgae growth (Honda et al., 2006; Chiemchaisri et al., 2007; Kaewsuk et al., 2010; Chitapornpan et al., 2012).

The photosynthetic treatment process has been applied to treat the wastewater and cultivate biomass. Various types of photosynthetic treatment process have been studied, for example, photosynthetic pond (Honda et al., 2006; Chiemchaisri et al., 2007), sequencing batch photobioreactor (Chitapornpan et al., 2012) including anaerobic membrane photo-bioreactor (Kaewsuk et al., 2010; Chitapornpan et al., 2013). In most of those treatment processes, PNSB are highly motile and attracted towards light sources, subsequently led to their accumulation on the reactor wall or lighting surface and thus decreasing light penetration into the reactor. In this research, novel photo-bioreactor with internal overflow recirculation was developed. It utilizes submersible pumps to recirculate slurry into series of vertical pipes which were placed above the liquid level, then allowed to overflow at the top and trickling down along the external surface of pipes. This recirculation help promoting contact between photosynthetic bacteria and wastewater. Thin layered PNSB formed on the pipe outer surface could effectively utilize organic substrates while directly absorbing infrared light, which supplied through the reactor wall. This allow the growth of PNSB biofilm only on the pipe surface for subsequent harvesting without any limitation of light penetration into the reactor.

This photo-bioreactor was also designed with higher surface-volume ratio (SVR) of $16.09 \mathrm{~m}^{-1}$ 
than other typical photo-bioreactors (with SVR less than $10 \mathrm{~m}^{-1}$ ) by arranging compact placement of pipes while minimizing shading effect of light supply.

In the microbial aspect of photo-bioreactor, majority of the previous studies were conducted using isolated pure culture and there were few studies on mix culture cultivation of photosynthetic biomass from wastewater (Honda et al., 2006; Chiemchaisri et al., 2007; Kaewsuk et al., 2010; Chitapornpan et al., 2012; Chitapornpan et al., 2013). To study the diversity of microbial in a mixed culture community, denaturing gradient gel electrophoresis of $16 \mathrm{~S}$ rDNA fragments, generated by polymerase chain reaction (PCR-DGGE) method was widely used to identify microbial community. The useful of this method was able to detect microbial even small percentages of microorganisms within a whole microbial community. Different sequences will migrate to different position in DGGE gel (Chitapornpan et al., 2013).

This research focuses on the investigation of organic removal efficiencies in photo-bioreactor with internal overflow recirculation for cultivation of photosynthetic biomass from fermented starch wastewater in laboratory scale experiment and determination of biomass characteristics in terms of biomass yield and photosynthetic pigment using Bchl.a and carotenoid contents. Moreover, the research studies bacterial community and predominant photosynthetic bacteria in mixed culture sludge using PCR-DGGE technique.

\section{Methodology}

\subsection{Photo-bioreactor set-up and operation}

The photo-bioreactor was made of acrylic flat plate, with internal dimensions of $0.30 \mathrm{~m}$ width x $0.3 \mathrm{~m}$ length x $0.7 \mathrm{~m}$ height and effective volume of $29.3 \mathrm{~L}$ (Fig. 1). Series of vertical pipes for internal overflow recirculation was installed within the reactor. Totally, the photobioreactor has twenty transparent acrylic pipes, each having $0.40 \mathrm{~m}$ in length and external diameter of $0.025 \mathrm{~m}$, connected by polyvinyl chloride (PVC) elbows and tee in each pair. Five submersible pumps were provided and connected with the acrylic tubes for making recirculating flow of slurry over the pipe surface. Submersible pumps lifted the mixed liquor into the pipes and allowed them to overflow at a rate of $4.16 \mathrm{l} / \mathrm{min}$, sufficient to create thin water film covering the surface pipe of 0.8-1 mm thickness. The height of acrylic pipes above 
the water level was set to $0.30 \mathrm{~m}$. The SVR, which is defined as a ratio of the lighted surface area to the effective volume of the reactor, was $16.09 \mathrm{~m}^{-1}$. A ceramic membrane $0.3 \mu \mathrm{m}$ pore size was installed inside the reactor to separate biomass from effluent and retain the biomass within the reactor. There was no biomass withdrawn from the reactor except for sampling purpose.

The bottom of reactor was covered with opaque plastic plate $(0.30 \mathrm{~m} \times 0.30 \mathrm{~m})$ all sides to prevent the light passing through. The infrared transmitting filter $(0.30 \mathrm{~m} \times 0.40 \mathrm{~m})$, (IR2880, Tsutsunaka Plastic Industry Co., Ltd., Japan), was used to cover outer surface of the reactor above the water level. This filter completely prevented the visible and ultraviolet wavelengths that promoted the algae growth and allowed only infrared wavelength to pass into the reactor. The reactor was illuminated for 24 hours per day by four incandescent lamps (60W) at a distance of $0.1 \mathrm{~m}$ from each side. The average infrared light intensity passed through each surface of the reactor was $12.73 \mathrm{~W} / \mathrm{m}^{2}$.

[Insert Figure 1]

Fermented starch wastewater was fed into the reactor once a day at a feeding rate of $2.9 \mathrm{l} / \mathrm{d}$ and kept a hydraulic retention time (HRT) at 10 days. Peristaltic pumps (Masterflex Easy load model 07528-20, Japan) were used to feed and withdraw wastewater and controlled by timers. The reactor was operated under anaerobic condition in the light radiation. The water bath was used as heat exchanger to control the temperature in range of $33-35^{\circ} \mathrm{C}$. The reactor was occasionally purged with $\mathrm{N}_{2}$ gas to keep the Oxidation Reduction Potential (ORP) below $-200 \mathrm{mV}$. The $\mathrm{pH}$ was maintained in the range of $7.0 \pm 1.0$ with $1 \mathrm{~N} \mathrm{NaHCO}_{3}$ or $1 \mathrm{~N} \mathrm{HCl}$.

\subsection{Fermented starch wastewater characteristic}

The experiment was conducted using fermented starch wastewater with highly organic concentrations from a noodle factory in Thailand. Table 1 shows the characteristics of wastewater used in this study. The biochemical oxygen demand (BOD) and chemical oxygen demand (COD) of wastewater were ranged from 221 to $1312 \mathrm{mg} / \mathrm{l}$ and 560 to $2620 \mathrm{mg} / \mathrm{l}$, respectively. Meanwhile, ammonia nitrogen $\left(\mathrm{NH}_{3}-\mathrm{N}\right)$ and total kjeldahl nitrogen (TKN) were ranged from 3.8 to $4.1 \mathrm{mg} / \mathrm{l}$ and 14 to $23 \mathrm{mg} / \mathrm{l}$, respectively. Sulfate content was ranged from 5.7 to $20.3 \mathrm{mg} / \mathrm{l}$ and suspended solids (SS) was 137 to $480 \mathrm{mg} / \mathrm{l}$. The chemical characteristics 
were performed according to the Standard Methods for Examination of Water and Wastewater (APHA, 1998).

[Insert Table 1]

\subsection{Inoculants}

The inoculants of photosynthetic bacteria in this study were enriched from the wastewater samples that were obtained from the noodle factory. According to the procedures proposed by Honda (2005), an enrichment medium of PNSB was prepared in screw caps test tubes of 20 ml, which (per liter) contained $1.0 \mathrm{~g}$ of $\mathrm{CH}_{3} \mathrm{COONa}, 0.5 \mathrm{~g}$ of $\mathrm{KH}_{2} \mathrm{PO}_{4}, 0.6 \mathrm{~g}$ of $\mathrm{K}_{2} \mathrm{HPO}_{4}, 0.8$ $\mathrm{g}$ of $\mathrm{NH}_{4} \mathrm{Cl}, 0.2 \mathrm{~g}$ of $\mathrm{MgSO}_{4} .7 \mathrm{H}_{2} \mathrm{O}, 0.2 \mathrm{~g}$ of $\mathrm{NaCl}, 0.05 \mathrm{~g}$ of $\mathrm{CaCl}_{2}, 0.1 \mathrm{~g}$ of Yeast extract. The medium was autoclaved at $121^{\circ} \mathrm{C}$ for 20 minutes and then, $1 \mathrm{ml}$ of vitamin solution and $1 \mathrm{ml}$ of trace metal solution were added into the medium. The vitamin solution (per liter) contained $200 \mathrm{mg}$ of thiamine- $\mathrm{HCl}, 500 \mathrm{mg}$ of Niacin, $300 \mathrm{mg}$ of $\rho$-aminobenzoic acid, 100 $\mathrm{mg}$ of pyridoxine-HCI, $50 \mathrm{mg}$ of vitamin $\mathrm{B}_{12}$ and $50 \mathrm{mg}$ of biotin. The trace metal solution (per liter) contained $1000 \mathrm{mg}$ of EDTA-2Na, $2000 \mathrm{mg}$ of $\mathrm{FeCl}_{3} \cdot 6 \mathrm{H}_{2} \mathrm{O}, 100 \mathrm{mg}$ of $\mathrm{ZnCl}_{2}, 85$ $\mathrm{mg}$ of $\mathrm{MnSO}_{4} \cdot 4 \mathrm{H}_{2} \mathrm{O}, 100 \mathrm{mg}$ of $\mathrm{H}_{3} \mathrm{BO}_{3}, 100 \mathrm{mg}$ of $\mathrm{CoCl}_{2} \cdot 6 \mathrm{H}_{2} \mathrm{O}, 20 \mathrm{mg}$ of $\mathrm{Na}_{2} \mathrm{MoO}_{4}, 10 \mathrm{mg}$ of $\mathrm{CuSO}_{4}, 10 \mathrm{mg}$ of $\mathrm{NiCl}_{2} \cdot 6 \mathrm{H}_{2} \mathrm{O}$ and $5 \mathrm{mg}$ of $\mathrm{NaSeO}_{3}$. The $0.1 \mathrm{ml}$ of fermented wastewater was added in the tubes and incubated at room temperature under anaerobic condition and light radiation. A 60W incandescent lamp was used as a light source. After two weeks of cultivation, the enriched culture was sub-cultured in new medium and transferred to new medium for 3 times before seeding into the reactor.

\subsection{Sample analysis}

During the experiment (day0 - day154), influent and effluent wastewater characteristics were monitored and collected every 7 days. Organic compounds in terms of Biochemical oxygen demand (BOD) and Chemical oxygen demand (COD) were determined by 5-day BOD method and closed reflux method. Filtered samples through GF/C filter paper were also analyzed for BOD and COD to determine the contribution of organic substances from soluble fraction of the samples. Total organic carbon (TOC) concentration was analyzed by a TOC analyzer (TOC-VCSH, Shimadzu, Japan). Suspended solids (SS) was determined by gravimetric method. Ammonia nitrogen $\left(\mathrm{NH}_{3}-\mathrm{N}\right)$ and Total Kjeldahl Nitrogen (TKN) were 
analyzed by distillation method and macro-kjeldahl method. Sulfate was analyzed by the turbidimetric method. The $\mathrm{pH}$, temperature and Oxidation Reduction Potential (ORP) were recorded using an analog data logger system (DL8C, China). Biomass production in terms of suspended solids in the reactor was monitored and represented by the cumulative biomass production and biomass yield. The protein concentrations of photosynthetic cells, crude protein and Lowry protein concentrations were determined by using the improved TKN method and Lowry's method. Photosynthetic pigments in terms of bacteriochlorophyll $a$ (Bchl.a) and carotenoids were analyzed according to the procedures described in Honda (2005). They are expressed as $\mu \mathrm{mol} / \mathrm{g}$ volatile suspended solids (VSS) and $\mathrm{mg} / \mathrm{g}$ VSS respectively.

\subsection{Photosynthetic bacteria community}

During the experiment, the study of suspended and attached bacteria communities in the reactor was carried out. At day 154, both suspended biomass and attached biomass samples were collected. The PCR-DGGE technique was used to study the diversity of bacteria and identified the species of bacteria both suspended and attached biomasses. The genomic DNA was extracted by applying the procedures described in the study of Zhou et al. (1996). The water sample was filtered through filter $(0.2 \mu \mathrm{m}$ nylon filter $)$. The $0.5-1 \mathrm{~g}$ of bacterial biomass filter was filled into the $1.5 \mathrm{ml}$ micro-centrifuge tube and mixed with $600 \mu \mathrm{l}$ of DNA extraction buffer (100 mM Tris-HCl pH 8.0,100 mM sodium EDTA pH8.0, $100 \mathrm{mM}$ sodium phosphate $\mathrm{pH} 8.0,1.5 \mathrm{M} \mathrm{NaCl}, 1 \% \mathrm{CTAB})$ and $10 \mu \mathrm{l}$ of lysozyme $(20 \mathrm{mg} / \mathrm{ml})$ and $100 \mathrm{ml}$ of proteinase $\mathrm{K}(10 \mathrm{mg} / \mathrm{ml})$ and then shaking at $225 \mathrm{rpm}$ at $37^{\circ} \mathrm{C}$ for $30-60 \mathrm{~min}$. After the shaking, $200 \mu \mathrm{l}$ of $20 \%$ SDS was added, and the sample was incubated in a water bath at $65^{\circ} \mathrm{C}$ for 1 hour with gentle end-over-end inversions every $20 \mathrm{~min}$. After that, the sample was centrifuged at $10,000 \mathrm{rpm}$ for $5 \mathrm{~min}$ at room temperature and the supernatant was collected into the $1.5 \mathrm{ml}$ micro-centrifuge tube. The sample was extracted by adding an equal volume of chloroform/isoamyl alcohol $(24: 1, \mathrm{v} / \mathrm{v})$ solution, mixing in a vortex mixer for $10 \mathrm{~s}$, centrifuging at 13,000 rpm for $5 \mathrm{~min}$ and then the supernatant was collected into the new 1.5 $\mathrm{ml}$ micro-centrifuge tube. The sample was precipitated with 0.6 volume of isopropanol $(6 \mathrm{ml}$ of isopropanol per $10 \mathrm{ml}$ of aqueous sample) at room temperature for 1 hour. Then, the pellet was obtained by centrifuging at 13,000 rpm for $10 \mathrm{~min}$ at room temperature and re-suspended the DNA pellet in $50 \mu \mathrm{l}$ sterile deionized water. The crude DNA solution was kept at $-20^{\circ} \mathrm{C}$ until being analyzed. 
For the study of bacterial diversity, two sets of primer were designed to amplify the extract DNA by the polymerase chain reaction (PCR). The primer set, 338GC-F forward primer and 518R reverse primer, was used to amplify the V3-16S ribosomal DNA (rDNA) region for the domain bacteria (Yanling et al., 2008; Mesquita et al. 2013; Chitapornpan et al. 2013). The PCR was performed in a Perkin-Elmer GeneAmp PCR System 9700 (Applied Biosystem, USA), with the conditions as follows; each $50 \mu \mathrm{l}$ of PCR reaction tube contained $20 \mathrm{ng}$ of genomic DNA template, $2 \mathrm{mM} \mathrm{MgCl} 2,0.2 \mathrm{mMdeoxynucleoside} \mathrm{triphosphate} \mathrm{(dNTPs),} 10 \mathrm{mM}$ of each primer and $1 \mathrm{U}$ of Taq DNA polymerase (Kapabiosystems, USA). The reaction began with $95^{\circ} \mathrm{C}$ denaturation for $5 \mathrm{~min}$, followed by 30 cycles of $95^{\circ} \mathrm{C}$ for $50 \mathrm{~s}, 60^{\circ} \mathrm{C}$ annealing step for $10 \mathrm{~s}$ with a $72^{\circ} \mathrm{C}$ extension step for $20 \mathrm{~s}$. Finally, the elongation step was carried out at $72^{\circ} \mathrm{C}$ for $7 \mathrm{~min}$. The second specific primer set, pufM 557F forward primer and pufM 750R reverse primer, was designed for amplify the pufM genes (Yanling et al., 2008; Chitapornpan et al. 2013), the encoding of $M$ subunit of the photosynthetic reaction center, which distributes the anoxygenic phototrophic bacteria (Yanling et al., 2008; Okubo, et al. 2006). The cycle started with initial denaturation at $95^{\circ} \mathrm{C}$ for $5 \mathrm{~min}$, followed by 30 cycles of $95^{\circ} \mathrm{C}$ for $50 \mathrm{~s}, 60^{\circ} \mathrm{C}$ annealing step for $10 \mathrm{~s}$ with a $72^{\circ} \mathrm{C}$ extension step for $25 \mathrm{~s}$ and the final extension step at $72^{\circ} \mathrm{C}$ for $7 \mathrm{~min}$. The PCR products were separated by $1.2 \%(\mathrm{w} / \mathrm{v})$ agarose gel electrophoresis strained with ethidium bromide. The list of primers used in this study are shown in Table 2.

[Insert Table 2]

DGGE analysis was performed to separate DNA fragments by using a DGGE-2000 system apparatus (CBS Scientific Company, Del Mar, CA, USA).In the first DGGE analysis of the domain bacteria primer set (338GC-F and 518R), the PCR samples were loaded to $7.5 \%$ $(\mathrm{w} / \mathrm{v})$ polyacrylamide gels in $0.5 \times \mathrm{xAE}$ (Tris-acetate-EDTA) buffer with a denaturing gradient between 40 to $65 \%$. A hundred percent of denaturant was corresponded to $7 \mathrm{M}$ urea and $40 \%$ $(\mathrm{v} / \mathrm{v})$ formamide. Electrophoresis was performed at a constant voltage of $80 \mathrm{~V}$ and a constant temperature of $60^{\circ} \mathrm{C}$ for 16 hours. Then, the gel was stained with ethidium bromide. The second DGGE analysis was performed with pufM primer set (557F and 750R) for photosynthetic bacteria. The PCR samples were applied on $10 \%(\mathrm{w} / \mathrm{v})$ polyacrylamide gels in $0.5 \times$ TAE buffer with a denaturing gradient between 45 to $70 \%$. A hundred percent of denaturant was corresponded to $7 \mathrm{M}$ urea and $40 \%(\mathrm{v} / \mathrm{v})$ formamide. The gel was run at a 
constant voltage and temperature of $80 \mathrm{~V}$ and $60^{\circ} \mathrm{C}$ for 16 hours. After 16 hours of electrophoresis, the gel was stained with ethidium bromide. The DGGE profiles were visualized on a UV trans-illuminator to observe band light intensity and captured the images by using Biovision CN 1000/26M (Vilber Lourmats, France). The most selected bands were excised from the gel and re-suspended into $200 \mu \mathrm{l}$ of MilliQ water. The DNA fragment was re-amplified with the same primer sets (338GC-F/518R and pufM 557F/pufM 750R) without GC-clamp. The amplified product was purified and used for DNA sequencing. The obtained nucleotide sequences were identified with the similar sequences of the reference organism from the available databases using the BLAST online software on the NCBI website (http://www.ncbi.nlm.nih.gov/) and aligned with the Gen Bank reference. The different of bacterial population between suspended growth and attached growth could be detected by the presence or absence of observed DNA bands and light intensity of bands.

\section{Results and discussion}

\subsection{Organics removal}

During the reactor operation period (154 days) at HRT of 10 days, the chemical characteristics of effluent and treatment performance of photo-bioreactor with internal overflow recirculation are presented in Fig. 2 and Table 3. With average influent BOD and COD concentrations of 953 and $1737 \mathrm{mg} / \mathrm{l}$, the organic loading rates into the reactor during the operation were $1640-7600 \mathrm{~g} \mathrm{COD} / \mathrm{m}^{3} \mathrm{~d}$. The $\mathrm{pH}$, temperature and ORP within the reactor were from 6.20 to $7.27,30.6$ to $33.9^{\circ} \mathrm{C}$ and -385 to $-60 \mathrm{mV}$, respectively. The fluctuation of ORP profile depended on the organic loading rate into the reactor, the ORP dropped significantly after feeding wastewater to system and gradually increased afterwards. Under dark condition (under water level) in the photo-bioreactor, PNSB can grow and utilize oxygen for their respiration when organic substances were fed into the system resulting in a decrease of ORP. Subsequently, the ORP value was raised to above $-200 \mathrm{mV}$ when organic substances in the photo-bioreactor became exhausted, which reduce the PNSB activity (Kaewsuk et al., 2010). The ORP profile changed was similar to the pattern observed in our previous study (Chiemchaisri et al., 2007). After the treatment, the effluent contained average BOD and COD concentrations of 41 and $182 \mathrm{mg} / \mathrm{l}$. The organic removal efficiency of BOD and COD were found to be $95 \%$ and $88 \%$ on average, which were higher than those reported 
in anaerobic membrane photo-bioreactor (51\%) treating similar type of wastewater (Chitapornpan et al., 2013). The function of this photo-bioreactor can be distinguished into two different zones, i.e. under (dark condition) and above (light condition) the water level. The dark zone below the water level was suitable for acidogenic and other heterotrophic bacteria to hydrolysis and metabolize starch and polysaccharide into organic acids. Above the water, the infrared light which pass through IR-filter promotes the growth of PNSB and converts organic acids to biomass. The recirculation of slurry helped promoting contact between wastewater and photosynthetic bacteria resulting in a higher treatment efficiencies than other conventional photo-bioreactors. PNSB cells are naturally small $(0.3-0.5 \mu \mathrm{m})$ and highly motile, thus, it is hard to separate them from a solution by gravity sedimentation. Ceramic membrane module of $0.3 \mu \mathrm{m}$ pore size installed for solid-liquid separation could effectively help retaining biomass in the photo-bioreactor. In the effluent, sulfate concentrations were lower than $10 \mathrm{mg} / 1$ with average removal of $61 \%$. During the start-up period (day 0-day 30), TKN and ammonia concentration in effluent wastewater were higher than influent because the reactor was initially started up with an enrichment medium of PNSB for cultivation, which included higher nitrogen than the influent wastewater. After the start-up period, the TKN and ammonia profiles decreased in the effluent because the nitrogen was utilized by the bacteria into their cell synthesis. During stable operation, TKN and ammonia concentrations in influent wastewater were 17.7 and $3.2 \mathrm{mg} / \mathrm{l}$. After treatment, TKN and ammonia removal efficiencies were $47 \%$ and $60 \%$ yielding average effluent TKN and ammonia concentrations of 8.4 and $1.4 \mathrm{mg} / \mathrm{l}$. In comparison to the previous studies, it was noticed that the organic removal obtained in this study was higher than the pond system using infrared transmitting filter at the same HRT (Chiemchaisri et al. 2007) even though the organic loading in this study was higher. The organic removal had the same level as the previous study using synthetic wastewater (Honda et al. 2006) despite of high fluctuation of real wastewater experienced in this study. The organic removal efficiencies obtained in this photo-bioreactor with internal overflow recirculation were also significantly improved from the anaerobic membrane photo-bioreactor employing only suspended biomass in treating similar types of wastewater and operating under fluctuations of wastewater characteristics (Chitapornpan et al., 2013). In this new type of photo-bioreactor, the growth of both suspended and attached photosynthetic biomass could be promoted. In suspended form, PNSB is supposed to grow together with acidogenic bacteria responsible for converting organic substances to VFAs under dark condition (Honda et al., 2006). The produced VFAs 
were then converted to photosynthetic biomass by PNSB biofilm attached on the pipes with the presence of light.

[Insert Figure 2]

[Insert Table 3]

\subsection{Photosynthetic biomass production}

Biomass production in the photo-bioreactor with internal overflow recirculation was monitored by determining suspended solid concentrations in slurry and attached biomass on overflow pipes. It was found that biomass has been better developed on overflow pipes as biofilm than in suspended solid concentrations and biofilm can be observed on the overflow pipes by visualization. Nevertheless, majority of biomass was found on the pipes as biofilm. Fig. 3 shows the accumulated biofilm along the external surface of pipes. At day 154, the samples of biofilm were collected from pipes at the height of 5, 10, 15, 20, 25 and $30 \mathrm{~cm}$ from water level. It was found that the accumulation of attached biomass was higher at the top of overflow pipes ( $30 \mathrm{~cm}$ from water level) and gradually decreased at the lower position. Since the development of attached biofilm was governed by water velocity and shear force between boundary layer of water and biofilm, the higher water velocity causes the thinner biofilm layer (Rijnaarts et al., 1993).

[Insert Figure 3]

During the operation period, total cumulative biomass production was $27.44 \mathrm{~g}$ dried solids. Among them, $22.62 \mathrm{~g}$ dried solids were found in attached growth form, of which accounted for $82 \%$ of total biomass production. The observed biomass yield was $0.51 \mathrm{~g}$ dried solids/g BOD removed and daily biomass production was $6.1 \mathrm{~g}$ dried solids $/ \mathrm{m}^{3} \mathrm{~d}$. This attached growth photosynthetic biomass production rate was found lower than those of other microorganisms cultivated in algal photo-bioreactor (Ruiz-Martinez et al. 2012) and photosynthetic bacteria in suspended growth form (Chitapornpan et al., 2013). Chitapornpan et al. (2013) reported the daily biomass productivity of $8.6 \mathrm{~g}$ dried solids $/ \mathrm{m}^{3} \mathrm{~d}$ with organic loading rate of food processing wastewater around 560 to $2605 \mathrm{~g} \mathrm{COD} / \mathrm{m}^{3} \mathrm{~d}$. One of the 
possible reasons is the fact that PNSB has a slower growth rate than other heterotrophic microorganisms, e.g. acid forming bacteria so they usually represent at a smaller fraction in the mixed culture biomass. This photo-bioreactor which promote selective growth of PNSB on the overflow pipes had lower observed biomass yield but not necessary lower PNSB growth.

The protein content of suspended biomass was monitored during the operating period. The mixed photosynthetic biomass had average protein content as crude protein of $0.58 \mathrm{~g} / \mathrm{g}$ dried solids. At day 154, the attached biomass samples were collected. The observed crude protein of attached biomass was $0.64 \mathrm{~g} / \mathrm{g}$ dried solids. The average crude protein of attached biomass was higher than suspended biomass because photosynthetic bacteria which accumulated at the pipes could easily absorb the light energy. Average lowery protein was found to be 0.44 $\mathrm{g} / \mathrm{g}$ dried solids. These values were higher than the protein contents of mix-culture photosynthetic biomass reported in other types of photo-bioreactor. More specifically, the average protein content of biomass in photo-bioreactor with internal overflow recirculation was found higher than that in the anaerobic membrane photo-bioreactor treating food processing wastewater with mixed culture photosynthetic biomass having crude protein and lowery protein of $0.37-0.41 \mathrm{~g} / \mathrm{g}$ dried solids and $0.27-0.32 \mathrm{~g} / \mathrm{g}$ dried solids, respectively (Chitapornpan et al., 2013). The photo-bioreactor with internal overflow recirculation can promote the growth of Rhodopseudomonas palustris in the form of biofilm which can directly absorb the infrared light. Vrati (1984) reported that Rhodopseudomonas palustris had higher crude protein than other types of PNSB. For other type of reactors, the sequencing batch photo-bioreactor had crude protein of $0.25-0.34 \mathrm{~g} / \mathrm{g}$ dried solids and lowery protein of $0.26 \mathrm{~g} / \mathrm{g}$ dried solids (Chitapornpan et al., 2012). Meanwhile, crude protein of $0.54 \mathrm{~g} / \mathrm{g}$ dried solids was obtained in photosynthetic bacteria pond system (Chiemchaisri et al., 2007). Average crude protein in this experiment, which were obtained in mixed culture cultivation, was comparable to crude protein of pure culture purple non-sulfur bacteria in the previous studies, which were reported to be $40 \%$ as crude protein for Rhodopseudomonas palustris (Getha et al., 1998), 53-70\% for Rhodobacter capsulatus (Driessens et al., 1987) and 72-74\% for Rhodopseudomonas palustris (Kim and Lee, 2000).

The mixed culture photosynthetic biomass developed within the reactor could be visualized as red to red-brown color because of an increase in carotenoid content of the biomass. The average photosynthetic pigments of mixed culture PNSB in terms of Bchl.a and carotenoids 
were observed at 0.29-1.65 $\mu \mathrm{mol} / \mathrm{gVSS}$ and 0.46-0.72 mg/gVSS. Meanwhile, Chitapornpan et al. (2013) reported that the observed carotenoid and Bchl.a content in mixed culture photosynthetic biomass were $0.7 \mathrm{mg} / \mathrm{gVSS}$ and $0.3 \mu \mathrm{mol} / \mathrm{gVSS}$ when being cultivated under mixed culture condition using food processing wastewater.

\subsection{Bacteria communities}

In the study of bacteria communities, PCR-DGGE was performed to identify microbial species within the photo-bioreactor (Table 4). Two samples were collected at day 154 as suspended sample from sludge and biofilm sample. Fig. 4 shows DGGE profiles of mixed culture from sludge sample and biofilm sample using 338GC-F/518R primer set. It was found that total 23 bands were detected; 11 bands of suspended biomass and 12 bands of attached biomass. From DNA sequence, they could be identified and classified into different groups as follow: $35 \%$ of Bacteroidetes (8/23), 56\% of Proteobacteria (13/23) and 9\% of Actinobacteria (2/23). Phylum Proteobacteria was the predominant bacterial group in both attached biomass (6/12) and suspended biomass (7/11) within the photo-bioreactor. Most of detected bands belong to Alphaproteobacteria, order Rhizobiales whereas 7 bands were identified to be the members of genus Pleomorphomonas, which was the nitrogen-fixing genera under anaerobic condition (Xie and Yokota, 2005; Im et al., 2006). In genus Rhodopseudomonas, 5 bands were detected. Only 1 band was detected in genus Methylobacteriaceae, which could reduce carbon compounds with one or more carbon atoms, such as, methane, methanol, $\mathrm{C}_{2}, \mathrm{C}_{3}$, and $\mathrm{C}_{4}$ compounds (Eller and Frenzel, 2001). As shown in Fig. 5, the highest band intensity of attached growth was found to be a member of genus Rhodopseudomonas (Rhodopseudomonas sp. S-1), which could grow on surfaces as biofilms (Honda, 2005, Okubo et al., 2006). While, in alpha subgroup the high band intensity of suspended growth was in genus Pleomorphomonas (Pleomorphomonassp. R5-392) but the highest band intensity was in phylum Bacteroidetes, class Sphingobacteria (Uncultured Sphingobacteriales bacterium clone Acro263), which had important role in hydrolysis of complex organic molecules (Chitapornpan et al., 2013). The Bacteroides can grow upon polysaccharides utilization. Wide variety of mono-, di-, and polysaccharides can serve as carbon and energy source as well as the major fermentation products includes succinate, propionate and acetate, with lesser amount of lactate, formate and malate (Smith et al., 2006). The bands of other groups in attached biomass were related to a member of Actinobacteria (2/12), family Nocardioidaceae (Propionicimonassp. F6), which could produce propionate from glucose 
(Akasaka et al., 2003). The DGGE profile of $338 \mathrm{GC}-\mathrm{F} / 518 \mathrm{R}$ primer set shows that the suspended biomass under the water level (anaerobic condition in the dark) included some type of bacteria which utilized macro-molecule starch and converted them to organic acid, such as, VFAs. Above the water level (anaerobic condition under the light), the attached biomass included photosynthetic bacteria in which Rhodopseudomonas became predominant. They can utilize VFAs and converted them to biomass cells. The corporate working between mixed cultures in this photo-bioreactor led to highly treatment performance of fermented starch wastewater. According to Honda et al. (2006), phototrophic growth of PNSB should the main bacterial activity at daytime. On the other hand, anaerobic chemotrophic growth such as other acidogenic bacteria or heterotrophic bacteria was the main bacterial activity at nighttime, even though a number of PNSB can also grow under anaerobic in dark condition. Even though the photo-bioreactor was continuously operated under anaerobic condition, methane gas produced by methanogens was negligible as the methane content detected in gas at the top of the photo-bioreactor was found to be only 6$6.5 \%$ at maximum.

[Insert Figure 4]

[Insert Table 4]

The second DGGE analysis was performed to identify anoxygenic photosynthetic bacteria with specific primer set (pufM 557F/750R). It was found that most of detected bacteria was in a member of genus Rhodopseudomonas (Rhodopseudomonas palustris pufL, pufM genes, Rhodopseudomonas palustris, Rhodopseudomonas sp. TUT3626 pufL, pufM genes). Likewise, the use of first primer set (338GC-F/518R) could detect photosynthetic bacteria in genus Rhodopseudomonas. They were considered as the major photosynthetic bacteria population within this system. The presence of Rhodopseudomonas palustris as predominant species in the photo-bioreactor was confirmed with the specific primer set. The presence of Rhodopseudomonas palustris in photo-bioreactor has also been reported in previous studies of cultivation mixed culture photosynthetic system (Chiemchaisri et al. 2007; Chitapornpan et al., 2013) but their predominance has not been confirmed. Fig. 5 shows DGGE profiles of mixed culture from sludge sample and biofilm sample using pufM 557F/750R primer sets, it was found that the higher band intensity was observed in attached biomass (lane 2) and it 
indicates a merit of using attached overflow pipes to promote selective growth of Rhodopseudomonas palustris.

[Insert Figure 5]

\section{Conclusions}

Photo-bioreactor with internal overflow recirculation was applied for conversion of organic carbon in real fermented starch wastewater to photosynthetic biomass. High BOD and COD removals of $95 \%$ and $88 \%$ were achieved in long term operation. Photosynthetic biomass yield was $0.51 \mathrm{~g}$ dried solid/g BOD removed and volumetric biomass production rate was 6.1

$\mathrm{g}$ dried solids $/ \mathrm{m}^{3} \mathrm{~d}$. The biomass contained average protein content of 56-64\% with average Bchl. $a$ and carotenoids pigment contents of $1.13 \mu \mathrm{mol} / \mathrm{gVSS}$ and $0.60 \mathrm{mg} / \mathrm{gVSS}$. Majority of biomass $(82 \%)$ was attached on the overflow pipes where selection of microbial population took place resulting in the predominance of Rhodopseudomonas palustris.

\section{Acknowledgements}

This research has been carried out under Research and Development of Water Reuse Technology in Tropical Region (WateR-InTro) project supported by Japan International Cooperation Agency (JICA) and Japan Science and Technology Agency (JST).

\section{References}

1. Akasaka, H., Ueki, A., Hanada, S., Kamagata, Y, Ueki, K., 2003. Propionicimonas paludicola gen. nov., sp. nov., a novel facultatively anaerobic, Gram-positive, propionateproducing bacterium isolated from plant residue in irrigated rice-field soil. Int. J. Syst. Evol. Micr. 53, 1991-1998.

2. American Public Health Association (APHA). 1998. Standard Method for the Examination of Water and Wastewater, 20th ad. American Public Health Association, Washington, DC.

3. Chiemchaisri, C., Jaitrong, L., Honda, R., Fukushi, K., Yamamoto, K., 2007.

Photosynthetic bacteria pond system with infra-red transmitting filter for the treatment and recovery of organic carbon from industrial wastewater. Water Sci. Technol. 56, 109-116. 
4. Chitapornpan, S., Chiemchaisri, C., Chiemchaisri, W., Honda, R., Yamamoto, K., 2012. Photosynthetic bacteria production from food processing wastewater in sequencing batch and membrane photo-bioreactor. Water Sci. Technol. 65, 504-512.

5. Chitapornpan, S., Chiemchaisri, C., Chiemchaisri, W., Honda, R., Yamamoto, K., 2013. Organic carbon recovery and photosynthetic bacteria production in an anaerobic membrane photo-bioreactor treating food processing wastewater. Bioresour. Technol. 65, 504-512.

6. Driessens, K., Liessens, J., Masduki, S., Verstraete, W., Nelis, H., DeLeeheer, A., 1987. Production of Rhodobacter capsulatus ATCC 23782 with short residence time in a continuous flow photobioreactor. ProcessBiochem. 22, 160-163.

7. Eller, G., Frenzel, P., 2001. Changes in Activity and Community Structure of MethaneOxidizing Bacteria over the Growth Period of Rice. Appl. EnvironMicrobiol. 67, 23952403.

8. Honda, R., 2005. Dissertation: Organic Wastewater Treatment by a photosynthetic Pond Process for Tropic Regions and Population Dynamics of Photosynthetic bacteria in the Pond. Department of Urban Engineering, The University of Tokyo.

9. Honda, R., Fukushi, K., Yamamoto, K., 2006. Optimization of wastewater feeding for single-cell protein production in an anaerobic wastewater treatment process utilizing purple non-sulfur bacteria in mixed culture condition. J. Biotechnol. 125, 565-573.

10. Im, W.T., Kim, S.H., Kim, M.K., Ten, L.N., Lee, S.T., 2006. Pleomorphomonas koreensis sp. nov., a nitrogen-fixing species in the order Rhizobiales. Int. J. Syst. Evol. Micr.56, 1663-1666.

11. Jackson, C.R., Roden, E.E., Churchill, P.F., 2000. Denaturing Gradient gel Electrophoresis can fail to separate 16S rDNA fragment with multiple base differences. Molecular Biol. Today. 1, 49-51.

12. Kaewsuk, J., Thorasampan, W., Thanuttamawong, M., Seo, G.T., 2010. Kinetic development and evaluation of membrane sequencing batch reactor (MSBR) with mixed cultures photosynthetic bacteria for dairy wastewater treatment. J. Environ. Manage. 91, 1161-1168.

13. Kim, J.K., Lee, B.K., 2000. Mass production of Rhodopseudomonas palustris as diet for aquaculture. Aquacul. Eng. 23, 281-293.

14. Liao, Q., Wang, Y.J., Wang, Y.Z., Zhu, X., Tian, X., Li, J., 2010. Formation and hydrogen production of photosynthetic bacterial biofilm under various illumination conditions. Bioresour. Technol. 101, 5315-5324. 
15. Mesquita, V.A., Magalhaes, K.T., Batista, C.F.S., Schwan, R.F., 2013. The Molecular Phylogenetic Diversity of Bacteria and Fungi Associated with the Cerrado Soil from Different Regions of Minas Gerais, Brazi. Int. J. Microbiol. Res. 4, 119-131.

16. Okubo, Y., Futamata, H., Hiraishi, A., 2006. Characterization of phototrophic purple nonsulfur bacteria forming colored microbial mats in a swine wastewater ditch. Appl. Environ.Microbiol. 72, 6225-6233.

17. Rijnaarts, H.H., Norde, W., Bouwer, E.J., Lyklema, J., Zehnder, A.J.B., 1993. Bacterial adhesion under static and dynamic conditions. Appl. Environ. Microbiol. 59,3255-3265.

18. Ruiz-Martinez, A., Garcia, N.M., Romeo, I., Seco, A., Ferrer, J., 2012. Microalgae cultivation in wastewater: nutrient removal from anaerobic membrane bioreactor effluent. Bioresour. Technol. 126, 247-253.

19. Smith, C.J., Rocha, E.R., Paster, B.J., 2006. The Medically Important Bacteroides spp. In Health and Disease. The Prokaryotes-A Handbook on the Biology of Bacteria, ${ }^{\text {rd }}$ Ed, Vol. 7, pp. 381-427.

20. Vrati, S. 1984. Single cell protein production by photosynthetic bacteria grown on the clarified effluents of biogas plant. Appl. Microbiol. Biotechnol. 19,199-202.

21. Xie, C.H., Yokota, A., 2005. Pleomorphomonas oryzae gen. nov., sp. nov., a nitrogenfixing bacterium isolated from paddy soil of Oryza sativa. Int. J. Syst. Evol. Micr. 55, $1233-1237$.

22. Yanling, Y., Zhenmei, L.V., Hang, M., Jun, C., 2008. Dynamic changes of microbial community diversity in a photohydrogen producing reactor monitored by PCR-DGGE. J. Environ. Sci. 20, 1118-1125.

23. Zhou, J., Brun, M.A., Tiedie, J.M., 1996. DNA Recovery from Soils of Diverse Composition. Appl. Environ.Microbiol. 62, 316-322. 
Table 1 Characteristic of influent fermented starch wastewater.

\begin{tabular}{|c|c|c|c|}
\hline Parameters & Unit & Range & Average \\
\hline $\mathrm{pH}$ & - & $6.0-7.3$ & 7.1 \\
\hline BOD & $\mathrm{mg} / \mathrm{l}$ & 221-1312 & 953 \\
\hline Soluble BOD* & $\mathrm{mg} / \mathrm{l}$ & $112-1114$ & 742 \\
\hline COD & $\mathrm{mg} / \mathrm{l}$ & $560-2620$ & 1737 \\
\hline Soluble COD* & $\mathrm{mg} / \mathrm{l}$ & 290-1960 & 1238 \\
\hline TOC & $\mathrm{mg} / \mathrm{l}$ & $101.5-1146$ & 837 \\
\hline $\mathrm{NH}_{3}-\mathrm{N}$ & $\mathrm{mg} / \mathrm{l}$ & $3.8-4.1$ & 3.2 \\
\hline TKN & $\mathrm{mg} / \mathrm{l}$ & $16.6-22.8$ & 17.7 \\
\hline SS & $\mathrm{mg} / \mathrm{l}$ & $137-480$ & 287 \\
\hline $\mathrm{SO}_{4}{ }^{2-}$ & $\mathrm{mg} / \mathrm{l}$ & $5.7-20.3$ & 11.6 \\
\hline
\end{tabular}

* Determined using filtered sample through GF/C paper 
Table 2 Oligonucleotideprimers used in this study.

\begin{tabular}{llr}
\hline Primer & Specificity & Sequence $\left(\mathbf{5}^{\prime} \boldsymbol{\rightarrow}\right.$ 3’) \\
\hline 338GC-F & Bacteria domain & *GC-ACTCCTACGGGAGGCAGC \\
518r & Bacteria domain & ATTACCGCGGCTGCTGG \\
pufM 557F-GC & Photosynthetic unit-forming gene & *GC-CGCACCTGGACTGGAC \\
pufM 750R & Photosynthetic unit-forming gene & CCCATGGTCCAGCGCCAGAA \\
\hline *GC: -CGCCCGGGGCGCGCCCCGGGCGGGGCGGGGGCACGGGGGGA
\end{tabular}


Table 3 Effluent qualities and removal efficiency in pipe overflow type photo-bioreactor.

\begin{tabular}{lccccc}
\hline Parameter & Unit & \multicolumn{2}{c}{ Effluent } & \multicolumn{2}{c}{ \% removal } \\
\cline { 3 - 6 } & & Range & Average & Range & Average \\
\hline BOD & $\mathrm{mg} / \mathrm{l}$ & $15.1-111$ & 41 & $80-98$ & 95 \\
$\mathrm{sBOD}$ & $\mathrm{mg} / \mathrm{l}$ & $11.9-68.0$ & 34 & $86-95$ & 90 \\
$\mathrm{COD}$ & $\mathrm{mg} / \mathrm{l}$ & $140-300$ & 182 & $70-94$ & 88 \\
$\mathrm{sCOD}$ & $\mathrm{mg} / \mathrm{l}$ & $88-192$ & 130 & $60-88$ & 79 \\
$\mathrm{NH}_{3}-\mathrm{N}$ & $\mathrm{mg} / \mathrm{l}$ & $0.6-3.8$ & 1.4 & $40-90$ & 60 \\
$\mathrm{TKN}$ & $\mathrm{mg} / \mathrm{l}$ & $4.1-10.4$ & 8.4 & $40-80$ & 47 \\
$\mathrm{SS}$ & $\mathrm{mg} / \mathrm{l}$ & $\mathrm{ND}$ & $\mathrm{ND}$ & 100 & 100 \\
$\mathrm{SO}_{4}{ }^{2-}$ & $\mathrm{mg} / \mathrm{l}$ & $1.1-9.2$ & 4.5 & $55-80$ & 61 \\
\hline
\end{tabular}

ND: Not Detected 
Table 4 Taxonomic affiliation of bacterial diversity obtained from the DGGE analysis. (338GC-F/518R)

\begin{tabular}{|c|c|c|c|c|c|}
\hline \multicolumn{2}{|c|}{ Phylogenetic affiliation } & \multicolumn{2}{|c|}{$\begin{array}{l}\text { Number of detected } \\
\text { bands }\end{array}$} & \multirow[t]{2}{*}{ Closet relative (accession no.) } & \multirow{2}{*}{$\begin{array}{c}\text { Simila } \\
\text { rity } \\
(\%)\end{array}$} \\
\hline & & Suspended & Attached & & \\
\hline Phylum & Bacteroidetes & & & & \\
\hline \multirow[t]{2}{*}{ Class } & Bacteroidia & & & & \\
\hline & & & $+^{\mathrm{a}}$ & Uncultured bacterium clone BR28 (GQ461636) & 96 \\
\hline \multirow[t]{3}{*}{ Family } & Porphyromonadaceae & & & & \\
\hline & & + & & Uncultured bacterium clone 5S1 (DQ663993) & 95 \\
\hline & & + & + & $\begin{array}{l}\text { Uncultured sulfate-reducing bacterium clone } 5 \\
\text { (AY652844) }\end{array}$ & 99 \\
\hline \multirow{3}{*}{$\begin{array}{l}\text { Class } \\
\text { Family }\end{array}$} & Cytophagia & & & & \\
\hline & Cytophagaceae & & & & \\
\hline & & + & + & Flexibacter sp. 1-O-7 (АВ272379) & 97 \\
\hline \multirow{4}{*}{$\begin{array}{l}\text { Class } \\
\text { Order }\end{array}$} & Sphingobacteria & & & & \\
\hline & Sphingobasteriales & & & & \\
\hline & & + & & $\begin{array}{l}\text { Uncultured Sphingobacteriales bacterium clone Acro263 } \\
\text { (KC110922) }\end{array}$ & 91 \\
\hline & & & + & $\begin{array}{l}\text { Uncultured Sphingobacteriales bacterium clone Acro263 } \\
\text { (KC110922) }\end{array}$ & 86 \\
\hline Total & & 4 & 4 & & \\
\hline Phylum & Proteobacteria & & & & \\
\hline Class & Alphaproteobacteria & & & & \\
\hline Order & Rhizobiales & & & & \\
\hline \multirow{6}{*}{ Genus } & Pleomorphomonas & & & & \\
\hline & & + & + & Pleomorphomonassp. R5-392 (JQ346801) & 99 \\
\hline & & & + & Pleomorphomonassp. R5-392 (JQ346801) & 99 \\
\hline & & + & & Alpha proteobacterium pACH82 (AY297802) & 99 \\
\hline & & + & + & Alpha proteobacterium pACH82 (AY297802) & 99 \\
\hline & & + & & $\begin{array}{l}\text { Pleomorphomonasoryzae strain: NBRC } 102288 \\
\text { (AB681744) }\end{array}$ & 98 \\
\hline \multirow[t]{5}{*}{ Genus } & Rhodopseudomonas & & & & \\
\hline & & & + & Rhodopseudomonas sp. S-1 (KC491187) & 100 \\
\hline & & + & + & Rhodopseudomonas sp. S-1 (KC491187) & 100 \\
\hline & & & + & Rhodopseudomonas sp. S-1 (KC491187) & 100 \\
\hline & & + & & R. palustris (X89815) & 100 \\
\hline \multirow[t]{2}{*}{ Genus } & Methylobacteriaceae & & & & \\
\hline & & + & & Methylobacteriumsp. DFW-AE7-6c (KC862019) & 97 \\
\hline Total & & 7 & 6 & & \\
\hline Phylum & Actinobacteria & & & & \\
\hline Order & Actinomycetales & & & & \\
\hline \multirow[t]{3}{*}{ Family } & Nocardioidaceae & & & & \\
\hline & & & + & Propionicimonassp. F6 (AY570689) & 99 \\
\hline & & & + & Propionicimonassp. F6 (AY570689) & 99 \\
\hline Total & & & 2 & & \\
\hline Total bands & & 11 & 12 & & \\
\hline
\end{tabular}




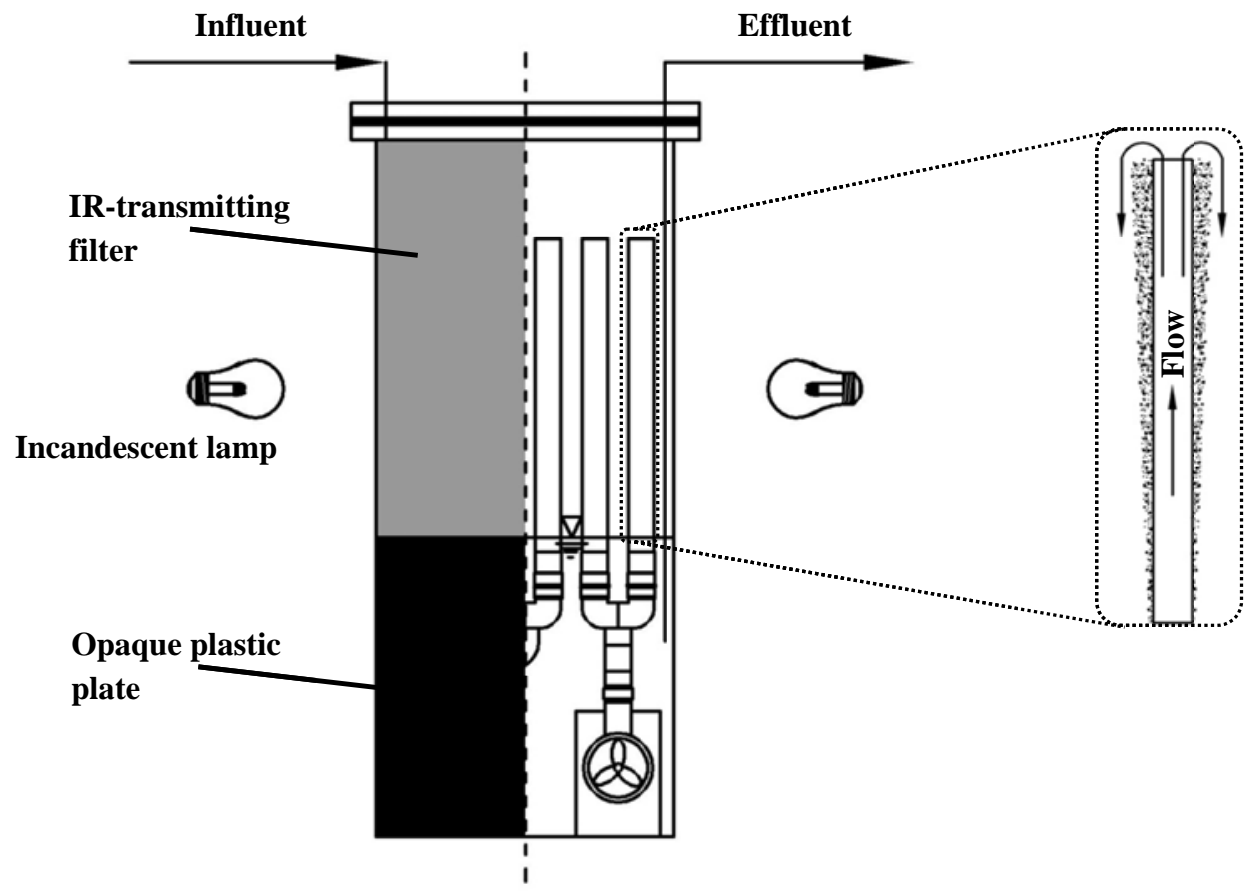

Fig. 1. Schematic of pipe-overflow-type photo-bioreactor 

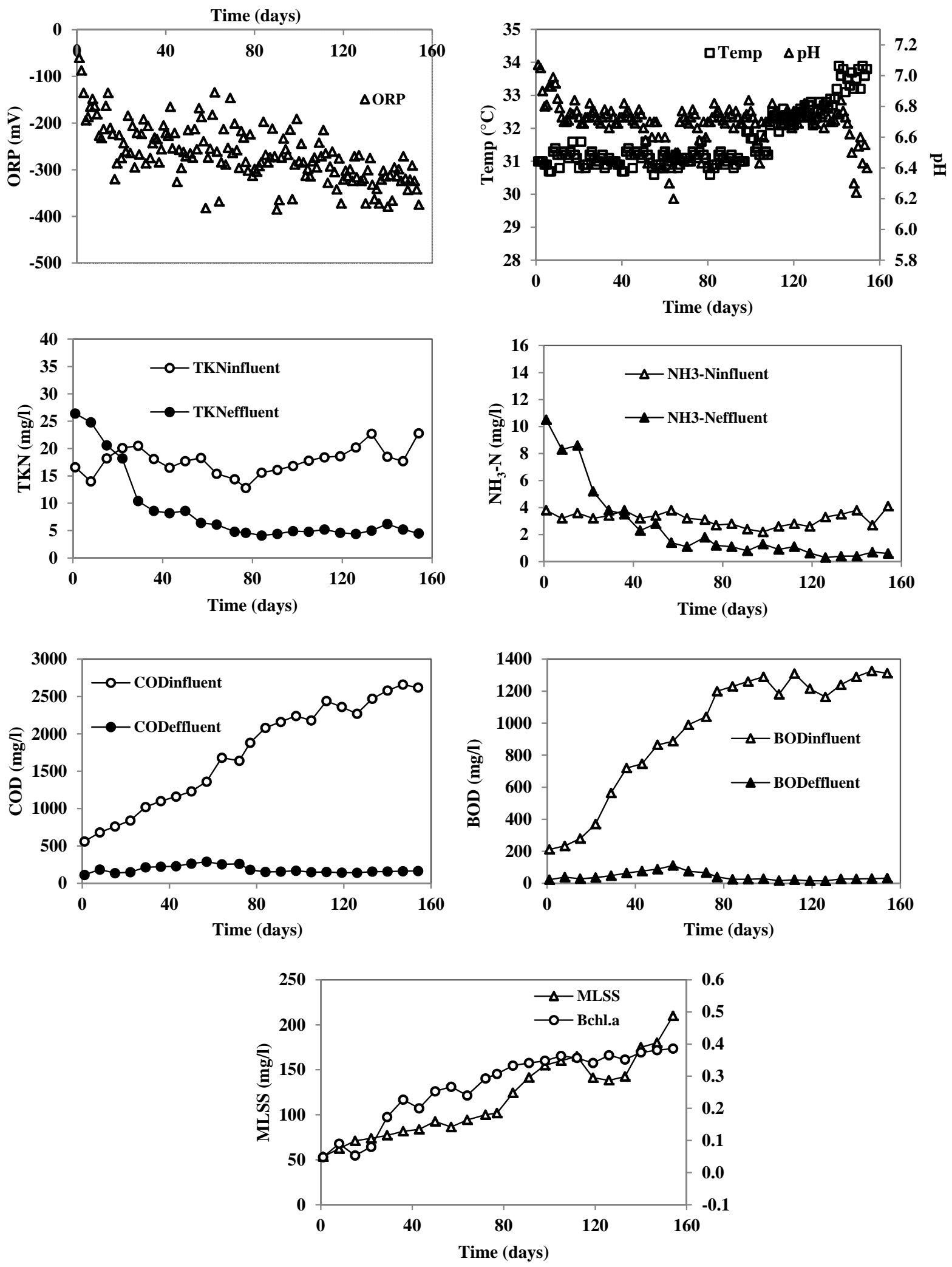

Fig. 2. Treatment performance of pipe-overflow-type photo-bioreactor during the operation 


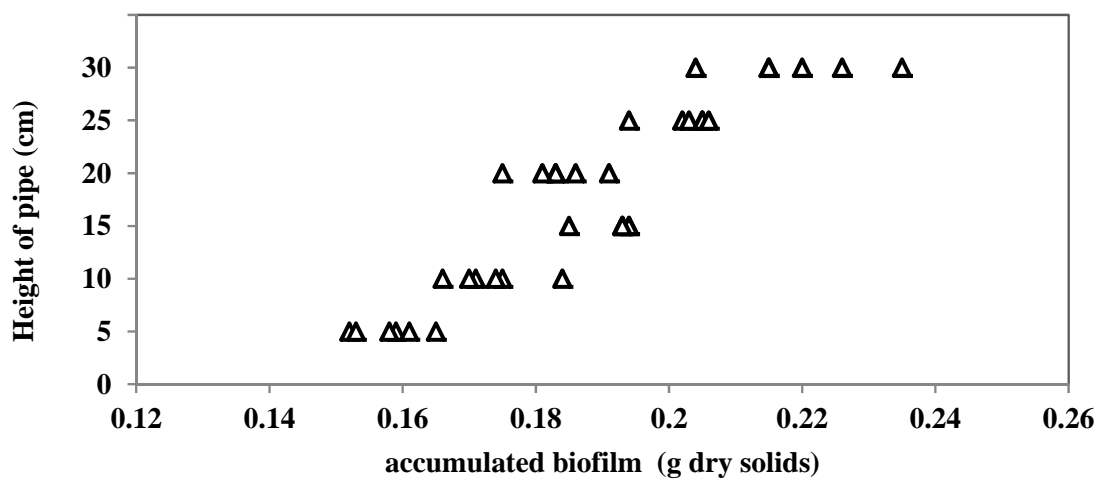

Fig. 3. Accumulated biofilm on the external surface of pipes. 


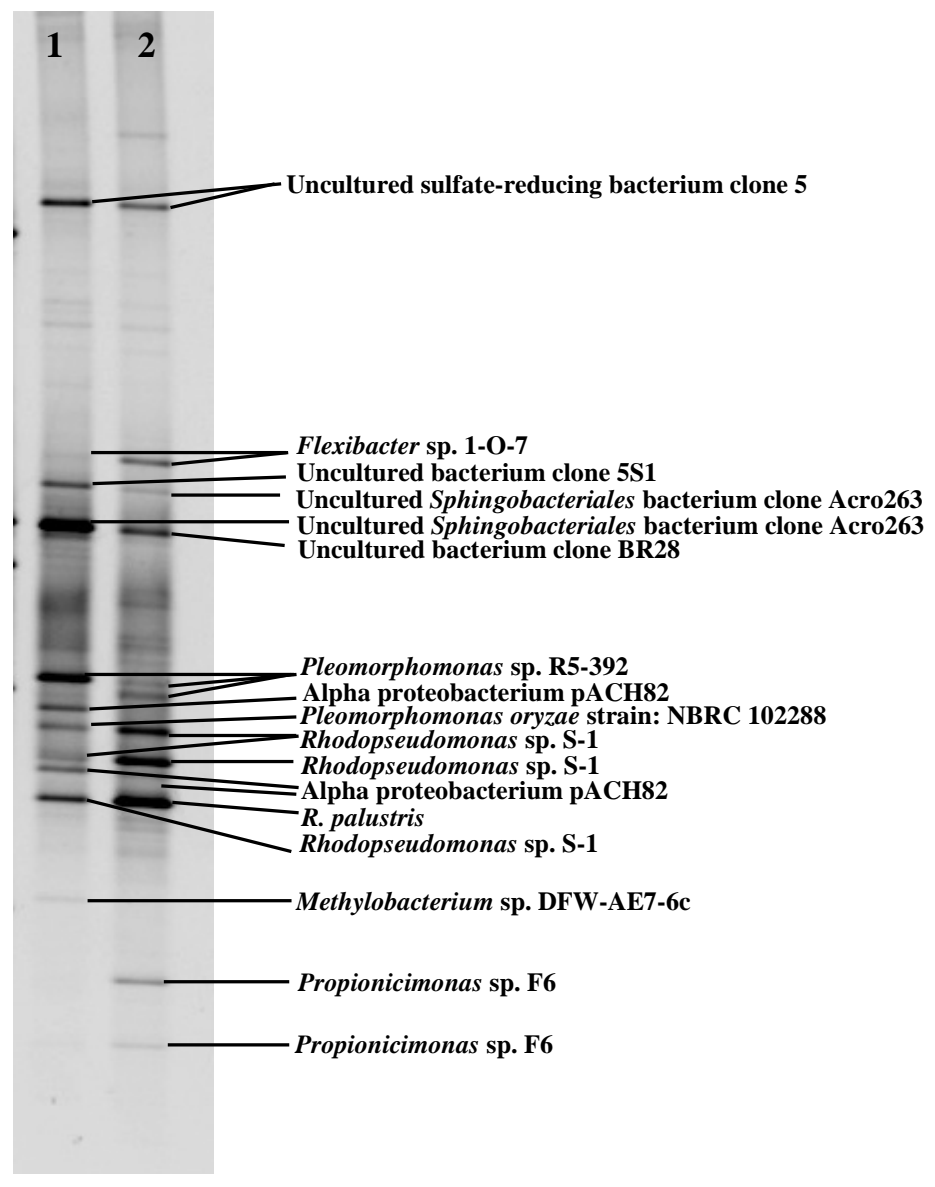

Fig. 4. DGGE profiles of PCR-amplified region 338GC-F and 518R of photosynthetic biomass samples. (1) Suspended biomass and (2) Attached biomass 


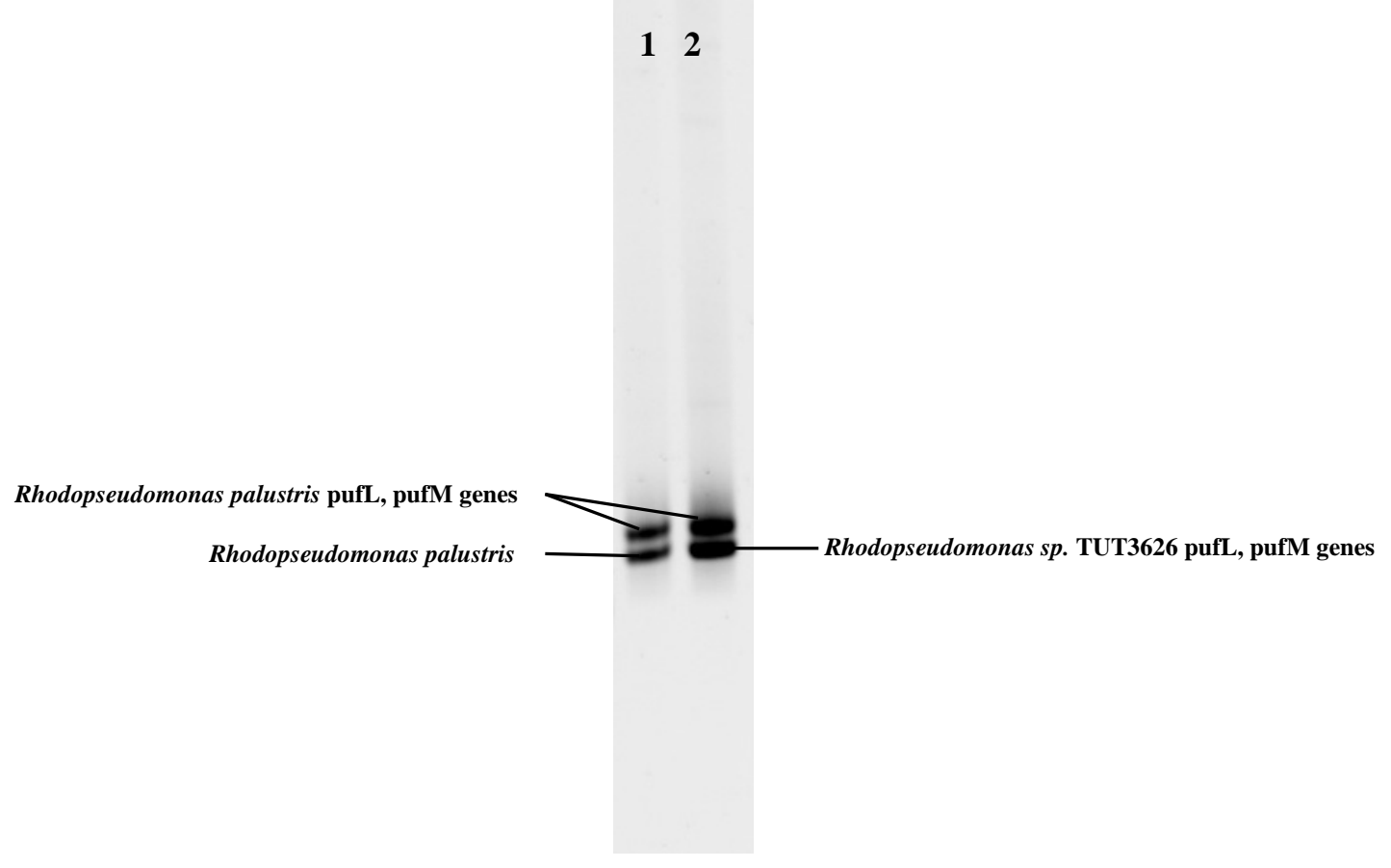

Fig. 5. DGGE profiles of of pufM 557F/750R amplification products from photosynthetic biomass samples. (1) Suspended biomass and (2) Attached biomass. 